\title{
Growth of forage palm cultivars irrigated with saline waters
}

\section{Crescimento de cultivares de palma forrageira irrigadas com águas salinas}

\author{
Mariana de Oliveira Pereira ${ }^{1 *}$; Jailton Garcia Ramos²; Beatriz de Araújo Tomaz; \\ João Henrique de Andrade $\mathrm{Cabral}^{3}$; Márcia Cristina de Araújo Pereira²; Carlos \\ Alberto Vieira de Azevedo4; Gustavo Bastos Lyra5; Patrícia Ferreira da Silva ${ }^{6}$
}

\section{Highlights}

Irrigation with saline water is essential for forage production in semiarid regions.

Forage palm cultivars differ in width, length, and thickness of cladodes.

The cultivars Orelha de Elefante and Miúda produce more cladodes.

\begin{abstract}
Forage palm (Cactaceae) is considered an important resource in the semiarid region of Brazil. This study aimed to analyze the effect of different levels of salinity in irrigation water on the growth of three forage palm cultivars. The study was conducted at the Federal University of Campina Grande (7 $12^{\prime} 52.6^{\prime \prime}$ S; $35^{\circ} 54^{\prime} 22.3^{\prime \prime}$ W) in $120 \mathrm{~L}$ pots open to the sky. The experiment was a complete randomized block, with four replications and a $4 \times 3$ factorial arrangement. The treatments consisted of four levels of salinity in irrigation water with electrical conductivity of $0.2,2.0,3.8$, and $5.6 \mathrm{dS} \mathrm{m}^{-1}$, and three forage palm cultivars: Miúda or Doce (Nopalea cochenillifera Salm Dyck), Orelha de Elefante (Opuntia stricta), and Baiana or IPA-Sertânia (Nopalea cochenillifera Salm Dyck). At 150 days after treatments, it was evaluated: length, width and perimeter of primary and secondary cladodes and total number of cladodes. Variance analysis was performed using an F-test $(p<0.05)$; significant effects were subjected to quadratic regression analysis for the quantitative

1 Doctorate in Agricultural Engineering, Technology and Natural Resources Center, Federal University of Campina Grande, UFCG, Campina Grande, PB, Brazil. E-mail: marianapereira.agri@gmail.com

2 Doctoral Scholar of Agricultural Engineering Course, Technology and Natural Resources Center, UFCG, Campina Grande, PB, Brazil. E-mail: jailtonbiossistemas@gmail.com; marciacristina794@gmail.com

${ }^{3}$ Graduating Student of Agricultural Engineering Course, Technology and Natural Resources Center, UFCG, Campina Grande, PB, Brazil. E-mail: beatriz-tomaz@hotmail.com; jandrade.cabral@gmail.com

${ }^{4}$ Prof., Post Graduate Program in Agricultural Engineering, Center of Technology and Natural Resources, UFCG, Campina Grande, PB, Brazil. E-mail: cvieiradeazevedo@gmail.com

${ }^{5}$ Prof., Department of Environmental Sciences, Forest Institute, Federal Rural University of Rio de Janeiro, UFRRJ, Seropédica, RJ, Brazil. E-mail: gblyra@ufrrj.br

${ }^{6}$ Post Doctor of the Post-Graduate Program in Engineering and Natural Resource Management, Department of Natural Reosurces, UFCG, Campina Grande, PB, Brazil. E-mail: patrycyafs@yahoo.com.br

* Author for correspondence
\end{abstract}

Received: June 25, 2020 - Approved: Mar. 07, 2021 
variable, and the Tukey test $(p<0.05)$ for the qualitative variable. Salinity levels in irrigation water did not affect the growth variables. There was a significant difference in the growth of forage palm as a function of its cultivar. The Baiana cultivar showed the highest vegetative growth of length and perimeter of primary and secondary cladodes, while Miúda and Orelha de Elefante presented the greatest cladode numbers for plant and cladode widths, respectively.

Key words: Electrical conductivity of irrigation water. Nopalea. Opuntia.

\section{Resumo}

A palma forrageira é considerada um importante recurso forrageiro no Semiárido brasileiro. Assim, objetivou-se avaliar o efeito de diferentes níveis de salinidade da água de irrigação no crescimento de três cultivares de palma forrageira. O estudo foi realizado na Universidade Federal de Campina Grande ( $7^{\circ} 12^{\prime} 52,56^{\prime} \mathrm{S} ; 3^{\circ} 54^{\prime} 22,26^{\prime \prime} \mathrm{O}$ ) em vasos de $120 \mathrm{~L}$ dispostos a céu aberto. O delineamento experimental foi em blocos casualizados em esquema fatorial $4 \times 3$, com 4 repetições. Os tratamentos consistiram de 4 níveis de salinidade da água de irrigação com condutividades elétricas de: 0,2; 2,0; 3,8 e 5,6 dS $\mathrm{m}^{-1}$; e três cultivares de palma forrageira: Miúda ou Doce (Nopalea cochenillifera Salm Dyck), Orelha de Elefante (Opuntia stricta), Baiana ou IPA Sertânia (Nopalea cochenillifera Salm Dyck). Aos 150 dias após o início dos tratamentos, avaliou-se: comprimento, largura e perímetro de cladódios primários e secundários e número de cladódios totais. As variáveis foram submetidas à análise de variância pelo teste $F(p<0,05)$ e quando houve efeito significativo foi realizada análise de regressão linear e quadrática para a variável quantitativa e o teste de Tukey $(p<0,05)$, para a variável qualitativa. Os níveis de salinidade da água de irrigação não exerceram influência sobre as variáveis de crescimento. Existe diferença significativa no crescimento da palma forrageira em função de sua cultivar. A cultivar Baiana apresenta crescimento vegetativo superior para comprimento e perímetro de cladódio primário e secundário, enquanto que as cultivares Miúda e Orelha de Elefante são superiores para número de cladódios por planta e largura de cladódio, respectivamente.

Palavras-chave: Condutividade elétrica da água de irrigação. Nopalea. Opuntia.

\section{Introduction}

The Brazilian semiarid region is marked by low pluviometric precipitation, high levels of evapotranspiration, and shallow soils with a reduced availability of nutrients and low water-holding capacity. According to Fonseca (2017), in the semiarid region soil and climatic conditions complicate the management of ruminant animals, limiting the production of natural pasture with a nutritional quality to supply animal feeding. The seasonality in forage production with plenty of food in the rainy season and a lack of it in the dry season is a major obstacle to rearing livestock.
In this context, forage palm related plants of the cactus family which remain productive in low-water conditions contributes to animal feeding in dry seasons. Galvão, Silva, Morais and Lima (2014) observed that the frequent cultivation and use of forage palm highlighted its importance as a resource in the feeding of ruminants. It is a valuable contribution to the water supply for animals, as it contains $90 \%$ water on average.

This is because it is a xerophyte that can survive in dry conditions, high temperatures, and poor soil fertility (Pereira, Silva, Zolnier, Morais, \& Santos, 2015). Its physiology is 
characterized by a photosynthetic process called crassulacean acid metabolism (CAM), which allows a hydric economy-closing the stomata during the day, and opening them and fixing $\mathrm{CO}_{2}$ at night. Despite its adaptation, production has been low, mainly due to a lack of proper management (Donato et al., 2014).

According to P. F. Silva etal. (2020), there was an increase in green-mass productivity of the order of $394 \mathrm{t} \mathrm{ha}^{-1}$ when forage palm was irrigated with $125 \%$ of reference evapotranspiration (ETO), compared with that on irrigation with $25 \%$ ET0, even when irrigated with saline water.

The main salts found are chlorides and sulfates of $\mathrm{Na}^{+}, \mathrm{Ca}^{2+}$, and $\mathrm{Mg}^{2+}$, with carbonates and nitrates in lesser quantities (Resende, Amorim, Cruz, \& Meneses, 2014). Saline and brackish water is an alternative resource utilized to mitigate water crisis, especially in semiarid and arid regions (Felix et al., 2018). However, inadequate management of saline irrigation can affect productivity due to excessive build-up of salts in the soil, which may degrade it and inhibit crop performance (Fonseca, 2017). Furthermore, the presence of a large amount of salt in the water can reduce plant osmotic potential, hamper water absorption through the roots, and interfere with the physiological processes-affecting growth and, consequently, productivity.

Accordingly, the present study aimed to analyze the effect of different irrigation salinity levels on the growth of three forage palm cultivars: Miúda or Doce (Nopalea cochenillifera Salm Dyck), Orelha de Elefante (Opuntia stricta), Baiana or IPA Sertânia (Nopalea cochenillifera Salm Dyck).

\section{Materials and Methods}

\section{Experimental site}

The study was conducted in an experimental area located on the campus of the Federal University of Campina Grande (UFCG), in the municipality of Campina Grande $\left(7^{\circ}\right.$ 12'52.56" S; 35 54' 22.26" W, 532 m altitude), the state of Paraiba, from November 2016 to July 2017. According to the Köppen climatic classification, widely adopted in Brazil, the region climate is the type Csa, mesothermal, sub-humid, with a hot dry season (4-5 months), and a rainy season from autumn to winter.

\section{Treatments and experimental design}

The experiment used the randomized complete block design, with 4 replications and a $4 \times 3$ factorial arrangement, with a total of 48 units. The treatments consisted of four levels of salinity in irrigation water with electrical conductivity of $0.2,2.0,3.8$, and $5.6 \mathrm{dS} \mathrm{m}^{-1}$, and three forage palm cultivars: Miúda or Doce (Nopalea cochenillifera Salm Dyck), Orelha de Elefante (Opuntia stricta), and Baiana or IPA Sertânia (Nopalea cochenillifera Salm Dyck). The treatments were applied 120 days after sowing (DAS).

\section{Experimental materials}

The research was conducted using 120 $\mathrm{L}$ pots open to the sky, with a space of $1.50 \mathrm{~m}$ between rows and $1.00 \mathrm{~m}$ between plants. To use pots as drainage lysimeters, two drains were inserted at the bottom of each pot. A layer of crushed stone was placed into the 
pots, covered with a textile fabric, a layer of coarse sand, and $170 \mathrm{~kg}$ of soil. The soil came from the Poço de Pedra farm, located in the countryside of the municipality of Santa Luzia, state of Paraiba.

The physicochemical characterization of the soil was performed in the Irrigation and Salinity Laboratory (LIS) of the Federal University of Campina Grande. The results were as follows: calcium $=5.49 \mathrm{cmol}_{\mathrm{c}} \mathrm{dm}^{-3}$; magnesium $=11.41 \mathrm{cmol}_{\mathrm{c}} \mathrm{dm}^{-3}$; sodium $=0.14$ $\mathrm{cmol}_{\mathrm{c}} \mathrm{dm}^{-3} ;$ potassium $=1.86 \mathrm{cmol}_{\mathrm{c}} \mathrm{dm}^{-3} ; \mathrm{S}$ (sum of bases) $=17.04 \mathrm{cmol}_{\mathrm{c}} \mathrm{dm}^{-3} ;$ hydrogen = 0.00; aluminum $=0.00 ;$ CTC (ionic exchange capacity) $=17.04$ cmolc dm-3; MO (organic matter $=1.20 \%$; nitrogen $=0.07 \%$; $\mathrm{pH}$ in $\mathrm{H}_{2} \mathrm{O}$ $(1: 2.5)=6.97 ; \mathrm{pH}$ (saturation extract) $=6.90 ; \mathrm{CE}$ (electrical conductivity of saturation extract) $=$ 0.64 ; sodium adsorption ratio $=0.26$; textural classification = sand; soil density $=1.42 \mathrm{~g}$ $\mathrm{cm}-3$; porosity $=47.01 \%$; available water $=$ 6.37; salinity = non-saline; soil classification = normal.

Cladodes of the three forage palm varieties came from the countryside of the municipality of Santa Luzia, Paraiba, where they were cut and remained for 15 days in the shade to recover (Gava \& Lopes, 2012). The cuttings were treated with a Bordeaux mixture $48 \mathrm{~h}$ before planting, (Motta, 2008). Cultivars were identified as C1- Miúda or Doce, C2- Orelha de Elefante, and C3- Baiana or IPA Sertânia. Fertilization occurred as recommended by Novais, Neves and Barros (1991). Nitrogen (N), phosphorus (P), and potassium (K) were applied monthly in the form of urea, potassium chloride $(\mathrm{KCl})$, and monoammonium phosphate (MAP), respectively. Total annual fertilization applied in each pot consisted of $15.11 \mathrm{~g}$ of urea, $42.5 \mathrm{~g}$ of $\mathrm{KCl}$, and $102.0 \mathrm{~g}$ of MAP.
Rainwater was collected and stored in a $5000 \mathrm{~L}$ polyethylene storage tank prior to usage to prepare treatments. Physicochemical characterization of rainwater was performed at the Irrigation and Salinity Laboratory (LIS) of the Federal University of Campina Grande. The results were the following: $\mathrm{pH}=6.67$; $\mathrm{CE}$ (electrical conductivity) $=0.027 \mathrm{dS} \mathrm{\textrm {cm } ^ { - 1 }}$; calcium $=1.20 \mathrm{mg} \mathrm{L}^{-1} ;$ magnesium $=2.40$

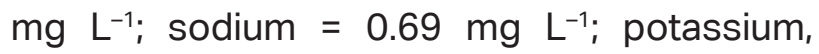
chloride, sulfate, carbonate, iron and alkalinity (carbonate) $=0.00 ;$ bicarbonate $=20.13 \mathrm{mg}$ $\mathrm{L}^{-1}$; alkalinity (bicarbonate) $=16.50 \mathrm{mg} \mathrm{L}^{-1}$; total hardness $=13.12 \mathrm{mg} \mathrm{L}^{-1}$; dry residue $=$ $17.64 \mathrm{mg} \mathrm{L}^{-1}$; free ammonia, nitrite and nitrate = absent. In the preparation of the treatment, commercial sodium chloride (without iodine), calcium chloride, and magnesium chloride were added to the water in the following proportion $7: 2: 1$, respectively, to elevate water electrical conductivity, as in the methodology proposed by Richards (1954). Irrigation management was carried out manually with a graduated cup using a two-day fixed irrigation. The water depth was obtained by real crop evapotranspiration (ETr) from drainage-lysimeter readings, which indicated the average balance of the entry and output of the water, keeping the humidity at values close to the field capacity over the crop cycle (Mantovani, Bernardo and Palaretti, 2012). Treatments were applied 100 days after planting cuttings in the pots when primary cladodes were visible in all plants which is the appropriate time to establish the crop.

To obtain meteorological parameters, an automatic weather station was used, located in the National Institute of Meteorology (INMET) $\left(7.22^{\circ} \mathrm{S}, 35.90^{\circ} \mathrm{W}\right.$, and $546 \mathrm{~m}$ altitude), approximately $1200 \mathrm{~m}$ from the experimental area. The plants were evaluated 150 days after the application of treatments (270 days 
after sowing) according to the methodology proposed by Borges, Matos, Silva, Dantas and Sobrino (2015). The variables evaluated were the number of cladodes (by counting), and length, width, and perimeter of primary and secondary cladodes (by measuring tape).

\section{Data analysis}

Data were subjected to a normality distribution test (Shapiro Wilk test; $p<0.05$ ), and an analysis of variance using the F-test ( $p$ $<0.01$ and $p<0.05$ ). Significant variables were subjected to linear and quadratic polynomial regression analysis for the quantitative factors (levels of salinity); the qualitative variables (cultivars) were subjected to a comparisonof-means test (Tukey test; $p<0.05$ ). Analyses were performed using the statistical software Sisvar, version 5.6 (Ferreira, 2014).

\section{Results and Discussion}

During the experiment, especially in the period between planting and growth evaluation (270 days), accumulated precipitation was about $512.70 \mathrm{~mm}$, with June and July being the wettest period. Accumulated precipitation was $484.20 \mathrm{~mm}$ at 150 days, when treatments began, and the growth was evaluated. The average temperature was $24.72^{\circ} \mathrm{C}$, with a mean daily maximum of $29.35^{\circ} \mathrm{C}$ and a minimum of $20.09^{\circ} \mathrm{C}$, and relative atmospheric humidity of $78.57 \%$.

\section{Primary cladodes}

Table 1 shows variance analysis (F-test; $p<0.01$ and $p<0.05$ ) of the length, width, and perimeter of the primary cladode at 270 days after sowing (DAS).

Table 1

Variance analysis of primary cladode length ( $P C L)$, primary cladode width (PCW), and perimeter of the primary cladode (PPC) at 270 DAS

\begin{tabular}{|c|c|c|c|c|}
\hline \multirow{2}{*}{ Source of variation } & \multirow{2}{*}{ DF } & \multicolumn{3}{|c|}{ Quadratic Average (QA) } \\
\hline & & PCL & PCW & PPC \\
\hline Salinity (S) & 3 & $4.05^{\mathrm{ns}}$ & $0.54^{\mathrm{ns}}$ & $41.03^{n s}$ \\
\hline Cultivar (C) & 2 & 460.67 * & 412.62 * & 624.47 * \\
\hline $\mathrm{S} \times \mathrm{C}$ & 6 & $14.56^{* *}$ & $1.42^{\mathrm{ns}}$ & $180.30^{\text {ns }}$ \\
\hline Block & 3 & $10.47^{\text {ns }}$ & $3.02^{\mathrm{ns}}$ & $66.94^{\mathrm{ns}}$ \\
\hline Error & 33 & 4.79 & 1.07 & 37.46 \\
\hline CV (\%) & & 6.90 & 6.62 & 8.27 \\
\hline General average & & 31.70 & 15.65 & 73.99 \\
\hline
\end{tabular}

$\left({ }^{*}\right)$; $\left.{ }^{* *}\right)$ - Significant at $p<0.01$ and $p<0.05$, respectively, by F-test; (ns) - Not significant. DF - degree of freedom. 
Table 1 shows significant statistical differences $(p<0.01)$ for all evaluated variables. However, salinity produced no significant effect on the variables studied. For the interaction between salinity and cultivar, the primary cladode length was significant at $\mathrm{p}<0.05$.

Regarding cultivar and salinity interactions, it was observed that the cultivar
Baiana had greater primary cladode length than other varieties for all salinity levels except $3.8 \mathrm{dS} \mathrm{m}^{-1}$ conductivity, which did not differ from the cultivar Miúda. Lower mean cladode lengths were observed for the Orelha de Elefante cultivar; however, it did not show a significant statistical difference from Miúda, except at a conductivity of $5.6 \mathrm{dS} \mathrm{m}^{-1}$ (Figure 1).
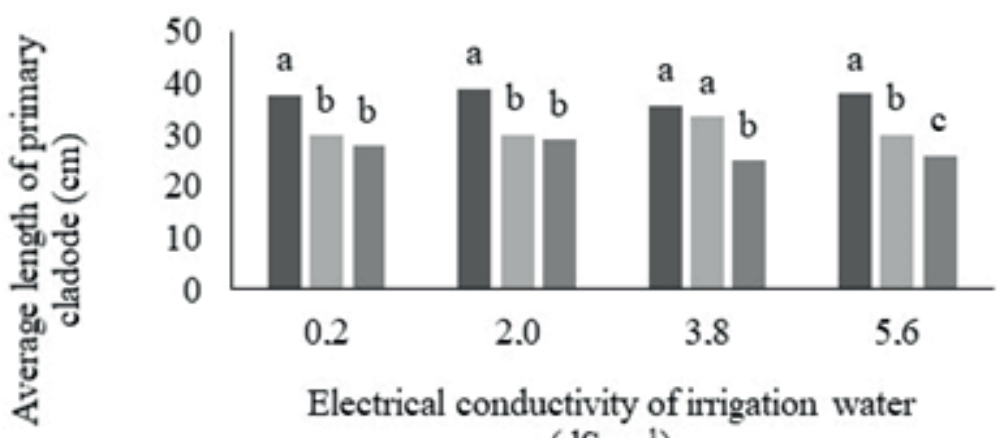

Electrical conductivity of irrigation water $\left(\mathrm{dS} \mathrm{m}{ }^{-1}\right)$

- Baiana " Miúda = Orelha

Figure 1. Analysis of the interaction between factors against average length of primary cladode of forage palm at 270 DAS. Equal lowercase letters do not differ statistically for cultivars by the Tukey test $(p<0.05)$.

In a study conducted by Fonseca (2017) of saline water usage in the forage palm Gigante (Opuntia fícus-indica), it was observed that this cultivar when irrigated with saline water of $3.6 \mathrm{dS} \mathrm{m}^{-1}$ conductivity developed an average cladode length of $27.47 \mathrm{~cm}$. In the present study, the cultivar Orelha de Elefante, belonging to the same genus (Opuntia), exhibited an average cladode length of 24.90 $\mathrm{cm}$ when subjected to a salinity level of 3.8 dS $\mathrm{m}^{-1}$, with an observed difference of $9.36 \%$ in the studies. According to Fonseca (2017), irrigation with saline water promotes better conditions for crop development.
According to Ramos et al. (2015), cladode dimension is important for absorbing light, storing water and producing a great proportion of the carbohydrates essential to the growth and development of cacti; these in turn improve photosynthesis and enhance productivity. Organs with great reserves have a major potential in their adaptation to salt stress.

According to R. H. D. Silva (2018), saline water with an electric conductivity of 4.78 $\mathrm{dS} \mathrm{m}^{-1}$ is a sustainable option for cultivars of Opuntia and Nopalea in dry seasons. In addition, Taiz and Zaiger (2016) pointed out 
that $\mathrm{Na}^{+}$(sodium) is a micronutrient for CAM (Crassulacean acid metabolism) plants, responsible for fixing carbon and indispensable for phosphoenolpyruvate regeneration (the substrate used in oxaloacetate production).
In the variance analysis results for cladode width, a significant effect was noted $(p<0.01)$ for differences in cultivar (Table 1). The statistically different cultivar, Orelha de Elefante, was the one with the greatest average cladode width of $20.76 \mathrm{~cm}$ (Figure 2).

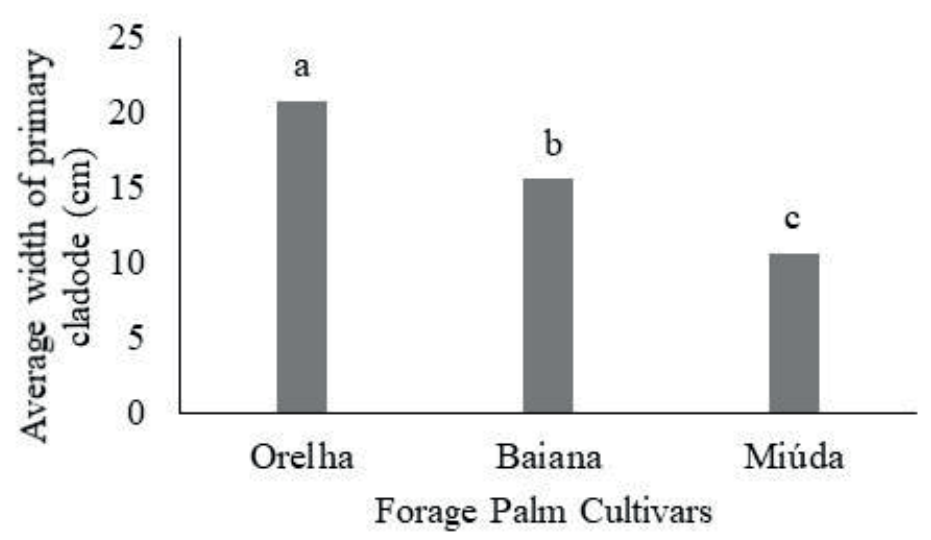

Figure 2. Average width of primary cladode at 270 DAS. Different letters indicate statistical difference by the Tukey test $(p<0.05)$.

The results found cladode width in the present work corroborate those achieved by Sales, Leite, Alves, Ramos and Nascimento (2013), in an experiment carried out in Soledade Paraiba, with forage palm (Opuntia fícus-indica Mill.), whose mean cladode width was greater than $16.03 \mathrm{~cm}, 360$ days after planting. It should also be noted that plant genetics, climate fluctuations, soil fertility, and irrigation management directly influence the length, width, and length of the cladodes, which is reflected in crop productivity.

According to Silva et al. (2015b), the Orelha de Elefante cultivar had the best results for cladode-width development over the evaluation, with the highest average of 16.8 $\mathrm{cm}$, followed by Baiana $(12 \mathrm{~cm}$ ) and Miúda (10 $\mathrm{cm})$. According to the same authors, these differences are associated with the anatomy of the Orelha cultivar, which favors plant width.

The primary cladode perimeter showed a statistically significant effect $(p<0.01)$ for the cultivar. Baiana showed the greatest average $(80.54 \mathrm{~cm})$, which differentiates it from the other cultivars. However, according to Tukey's test ( $p<0.05$ ), Miúda and Orelha cultivars did not show statistical differences from each other (Figure 3). 


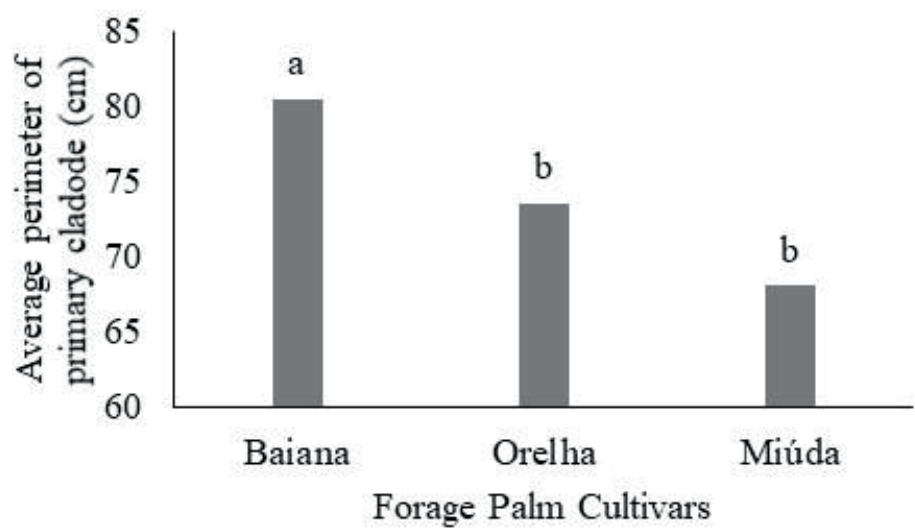

Figure 3. Average perimeter of primary cladode at 270 DAS. Different letters indicate statistical difference by the Tukey test $(p<0.05)$.

Borges et al. (2015) analyzed the growth of the same forage palm cultivars and obtained a greater average cladode perimeter for the cultivar Baiana with $60.50 \mathrm{~cm}$ at 210 DAS. By comparison, the present study observed an average perimeter of Baiana approximately $25 \%$ higher. This difference may be due to the evaluation period; in this study measurements were conducted at 270 DAS.

Silva et al. (2015a) stated that the perimeter of the cladodes of the cultivars Orelha de Elefante and IPA-Sertânia (Baiana) had the same behavior, corresponding to an average of 57 and $54 \mathrm{~cm}$, respectively. The cultivar Miúda, on the other hand, had a smaller perimeter than the other cultivars studied, which is supported by the present study.

\section{Secondary cladodes}

Variance analysis for length, width, and perimeter of the secondary cladode and the number of total cladodes at 270 DAS are shown in Table 2.

Table 2

Variance analysis of secondary cladode length (SCL), secondary cladode width (SCW), perimeter of secondary cladode (PSC), and total number of cladodes (TNC) at 270 DAS

\begin{tabular}{cccccc|} 
Source of variation & DF & \multicolumn{2}{c|}{ Quadratic Average (QA) } \\
\cline { 3 - 5 } & & $\mathrm{SCL}$ & $\mathrm{SCW}$ & $\mathrm{PSC}$ & $\mathrm{TNC}$ \\
\hline Salinity (S) & 3 & $0.82^{\text {ns }}$ & $1.71^{\text {ns }}$ & $105.60^{\text {ns }}$ & $23.17^{\text {ns }}$ \\
Cultivar (C) & 2 & $477.20^{*}$ & $210.59^{*}$ & $2315.32^{*}$ & $2045.39^{*}$ \\
\hline S x C & 6 & $10.11^{\text {ns }}$ & $4.25^{\text {ns }}$ & $80.78^{\text {ns }}$ & $51.48^{* *}$ \\
\hline Block & 3 & $10.02^{\text {ns }}$ & $4.55^{\text {ns }}$ & $61.27^{\text {ns }}$ & $24.56^{\text {ns }}$ \\
\hline Error & 33 & 10.02 & 2.62 & 72.21 & 17.33 \\
\hline CV (\%) & & 12.83 & 11.23 & 14.43 & 17.97 \\
\hline General average & & 24.67 & 14.11 & 58.88 & 23.17 \\
\hline
\end{tabular}

$\left.\left({ }^{*}\right) ;{ }^{* *}\right)$ - Significant at $p<0.01$ and $p<0.05$, respectively, by F-test; $\left({ }^{n s}\right)-$ Not significant. DF - degree of freedom. 
The findings (Table 2) verify some statistically significant differences $(p<0.01)$ for all growth variables evaluated. Some significance $(p<0.05)$ was also found for the interaction [cultivar $\times$ salinity] regarding the total number of cladodes.

The Baiana cultivar showed a greater average length for the secondary cladode
$(30.96 \mathrm{~cm})$, which was statistically different from the others $(p<0.01)$. However, the Miúda and Orelha cultivars did not show any statistical difference from each other, with an average cladode length of 21.96 and $21.09 \mathrm{~cm}$, respectively (Figure 4).

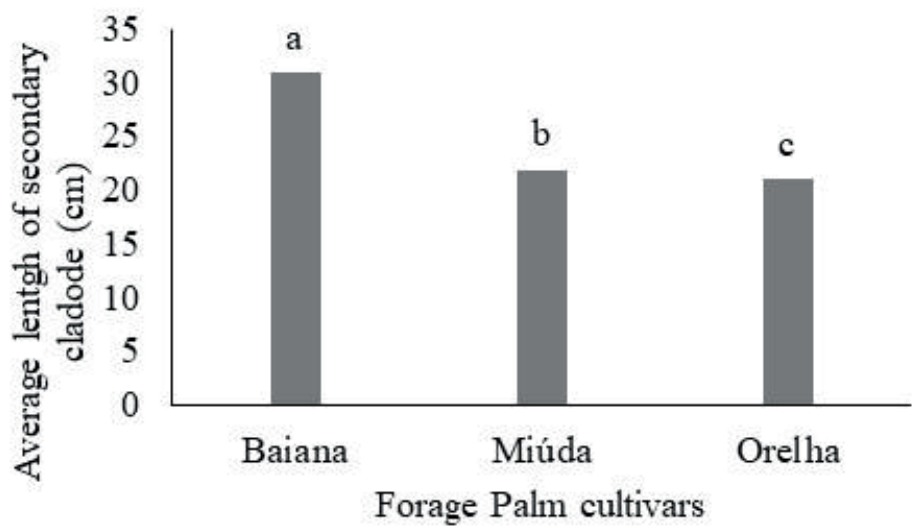

Figure 4. Average length of secondary cladode at 270 DAS. Different letters indicate statistical difference by the Tukey test $(p<0.05)$.

Cavalcante, Santos, Silva, Fagundes and Silva (2014) affirm that the length of the cladode is dependent on the genotype, so the genotypes of Gigante (Opuntia fícus-indica) present greater cladode length when compared to Redonda and Miúda, which characteristically have wider cladodes. However, with their more developed and well-structured cladodes, they accordingly have more lignified tissues. This issue was encountered in the present study, since the Baiana cultivar had greater lengths than Miúda and Orelha.

Silva et al. (2015b) studied the morphological characteristics of the same forage palms (Baiana, Miúda, and Orelha) under mineral fertilization and obtained a higher average length of cladode at 60 DAS.
According to the Tukey test ( $p<$ 0.05), only the cultivar variation significantly influenced the secondary cladode width (Table 2). The Orelha de Elefante cultivar presented the highest average for this variable (17.41 $\mathrm{cm})$, followed by Baiana $(15.44 \mathrm{~cm})$ and Miúda $(10.37 \mathrm{~cm})$. All cultivars differed from each other (Figure 5).

Investigating morphometry and forage palm yield under different doses of organic fertilization at different spacings, Donato et al. (2014) observed an average cladode width of $16.3 \mathrm{~cm}$ at 600 DAS, a similar value to that found in this research with the Orelha de Elefante cultivar. These are different cultivars, but belong to the same genus (Opuntia). 
According to studies conducted by Ramos et al. (2015) the growth of forage palm has its genetic characteristic as a hypothesis, that is, plants belonging to Opuntia show a horizontal growth while the ones belonging to Nopalea show a vertical growth.
Regarding the perimeter of the cladode, there were some statistical differences $(p<$ 0.01) among cultivars that were evaluated (Table 2). The Baiana cultivar showed higher average perimeter $(72.54 \mathrm{~cm})$, while the other cultivars did not differ from each other, presenting an average perimeter of $52.05 \mathrm{~cm}$ (Figure 6).

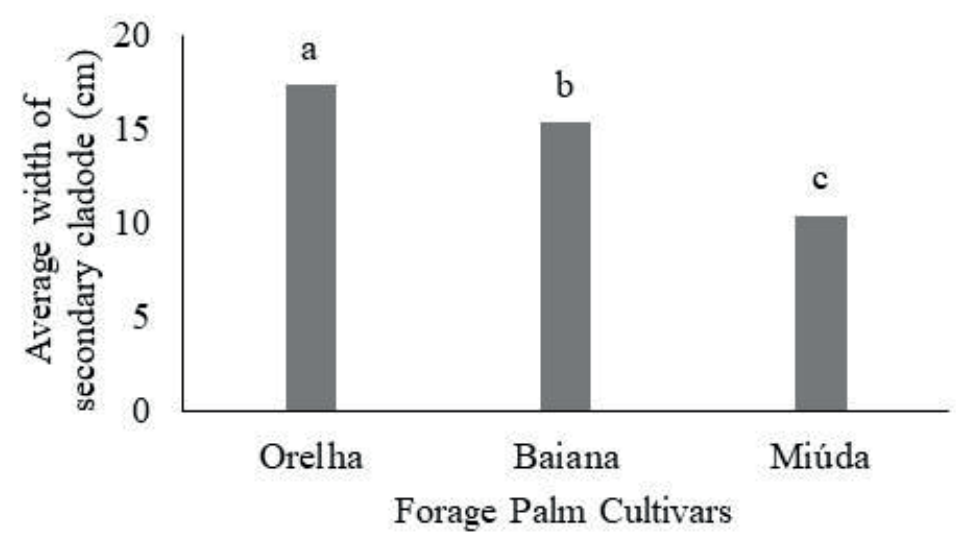

Figure 5. Average width of secondary cladode at 270 DAS. Different letters indicate statistical difference by the Tukey test $(p<0.05)$.

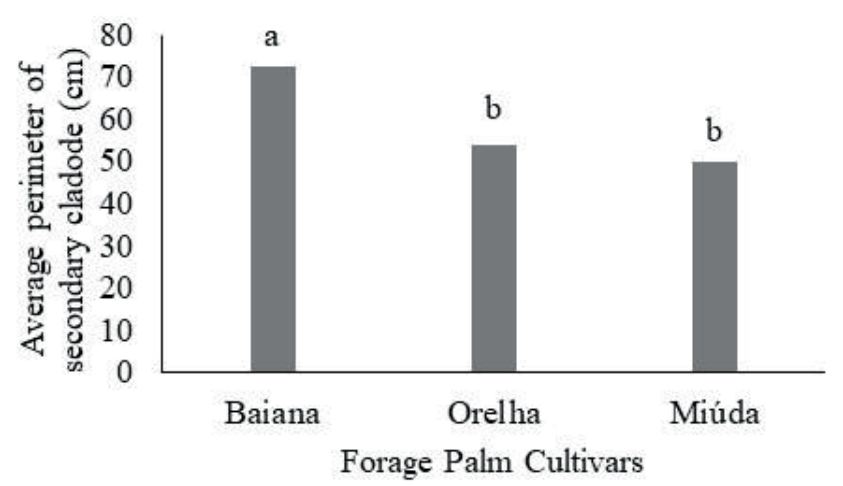

Figure 6. Average perimeter of secondary cladode at 270 DAS. Different letters indicate statistical difference by the Tukey test $(p<0.05)$.

Silva et al. (2015b) obtained primary cladode perimeters of $75.88 \mathrm{~cm}$ for Orelha de Elefante, IPA-Sertânia (Baiana) $61.72 \mathrm{~cm}$, and Miúda $31.28 \mathrm{~cm}$ at 745 days.
By comparison, the present study noted an average perimeter of $16.70 \%$ (for the same planting time), which is higher than the values found by Silva et al. (2015b). Regardless 
of salinity levels, irrigation may have improved the plant growth metrics; forage palm growth and productivity respond positively to water availability (P. F. Silva et al., 2020).

The total number of cladodes was significantly influenced by cultivar $(p<0.01)$ and by the interaction of salinity $(p<0.05$; Table 2).
The results obtained through the interaction [cultivar $\times$ salinity] showed that the maximum salinity levels for Miúda and Baiana

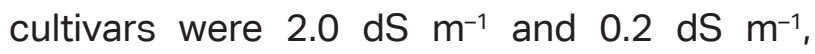
respectively; at these values, a decrease in the total number of cladodes occurred. The Orelha cultivar showed a decrease in the number of total cladodes at a salinity level of $3.8 \mathrm{dS} \mathrm{m}^{-1}$ (Figure 7).

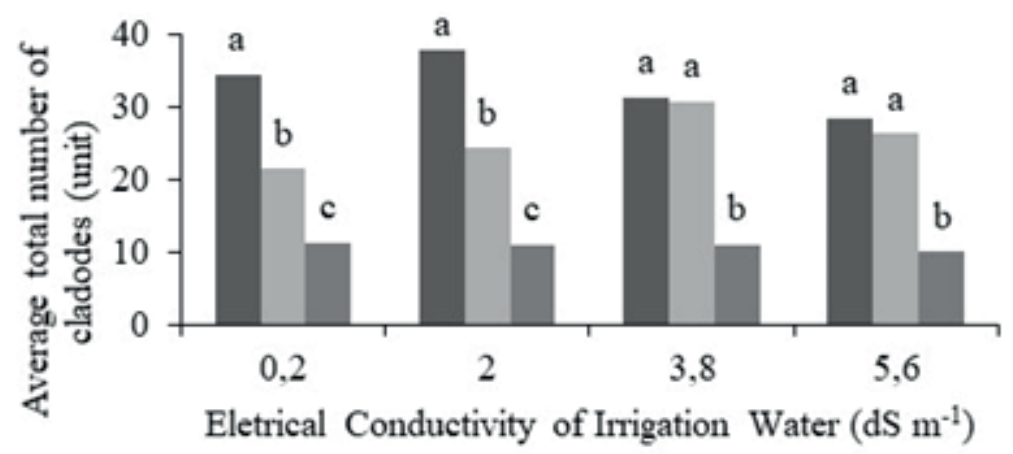

" Miúda =Orelha = Baiana

Figure 7. Analysis of the interaction between factors against average total number of cladodes of forage palm at 270 DAS. Equal lowercase letters do not differ statistically by the Tukey test ( $p<$ 0.05).

Miúda cultivar presented the greatest average of total cladodes for all salinity levels, with a maximum value of 37.75 with salinity level of $2.0 \mathrm{dS} \mathrm{m}^{-1}$. The cultivar Orelha de Elefante showed the second highest average number of cladodes (30.75) at a salinity level of $3.8 \mathrm{dS} \mathrm{m} \mathrm{m}^{-1}$. Baiana showed the lowest total number of cladodes, with a maximum value of 11.25 at a salinity level of $0.2 \mathrm{dS} \mathrm{m}^{-1}$.

The observed decrease in average numbers of cladodes within the same cultivar was $24.50 \%, 14.63 \%$, and $11.11 \%$, respectively, for Miúda, Orelha, and Baiana. However, at the low salinity level of $1.0 \mathrm{dS} \mathrm{m}^{-1}$ it was observed that Baiana presented the lowest decrease of this variable, followed by Miúda and Orelha.
In this context, it is noteworthy that both cultivars, Miúda and Baiana, belong to the same genus (Nopalea), whereas Orelha belongs to Opuntia. Thus, cultivars belonging to Nopalea were the least affected by the gradual increase of salinity in irrigation water; however, they were inferior to the Opuntia in terms of maximum salinities tolerated.

Felix et al. (2018) reported that the highest number of forage palm cladodes was obtained at an irrigation water salinity level of $1.5 \mathrm{dS} \mathrm{m} \mathrm{m}^{-1}$, with the lowest values for the variable obtained at the levels of $3.0,4.5$, and $6.0 \mathrm{dS} \mathrm{m}^{-1}$.

Precipitation probably influenced the cumulative salinity effect on cultivars. 
This in turn would be influenced by the soil texture (sandy soil), which may have favored the leaching of salts from soils that had been irrigated with saline water.

\section{Conclusions}

Salinity levels in water irrigation did not influence the growth variables of forage palm under the conditions of the experiment.

There was a significant difference in forage palm growth as a function of the cultivar. The Baiana cultivar demonstrated superior growth (length and perimeter) of primary and secondary cladodes, whereas Miúda and Orelha were superior in cladode number, considering plant and cladode width, respectively.

\section{Acknowledgements}

The present work was conducted with the support of the National Council for Scientific and Technological Development (CNPq) and the Federal University of Campina Grande (UFCG).

\section{References}

Borges, V. E., Matos, R. M., Silva, P. F., Dantas, J., Neto, \& Sobrino, T. G. (2015). Análise de crescimento de três cultivares de palma forrageira. Educação Agrícola Superior, 30(2), 7-14. doi: 10.12722/0101-756X.v30 $\mathrm{n} 02 \mathrm{a} 07$

Cavalcante, L. A. D., Santos, G. R. A., Silva, L. M., Fagundes, J. L., \& Silva, M. A. (2014). Respostas de genótipos de palma forrageira a diferentes densidades de cultivo. Pesquisa Agropecuária Tropical, 44(4), 424-433. doi: 10.1590/S1983-40 632014000400010

Donato, P. E. R., Pires, A. J. V., Donato, S. L. R., Bonomo, P., Silva, J. A., \& Aquino, A. A. (2014). Morfometria e rendimento da palma forrageira 'Gigante' sob diferentes espaçamentos e doses de adubação orgânica. Revista Brasileira de Ciências Agrárias, 9(1), 151-158. doi: 10.5039/ agraria.v9 i1a 3252

Felix, E. S., Lima, W. B., Silva, C. T., Araújo, J. S., Pereira, D. D., \& Lira, E. C. (2018). Cultivo de palma forrageira (Opuntia Stricta) irrigada com água salinizada. Brazilian Applied Science, 2(6), 1869-1875.

Ferreira, D. F. (2014). Sisvar: a computer statistical analysis system. Ciência e Agrotecnologia, 35(6), 1039-1042. doi: 10. 1590/S1413-70542011000600001

Fonseca, V. A. (2017). Estratégia de utilização de água salina no cultivo de palma forrageira 'Gigante'. Dissertação de mestrado, Instituto Federal de Educação, Ciência e Tecnologia Baiano, BA, Brasil.

Galvão, J. G. B., Jr., Silva, J. B. A., Morais, J. H. G., \& Lima, R. N. (2014). Palma forrageira na alimentação de ruminantes: cultivo e utilização. Acta Veterinaria Brasilica, 8(2), 78-85. doi: 10.21708/avb.2014.8.2

Gava, C. A. T., \& Lopes, E. B. (2012). Produção de mudas de palma forrageira utilizando fragmentos de cladódios. Petrolina, PE: Editora EMBRAPA.

Mantovani, S. C., Bernardo, S., \& Palaretti, L. F. (2012). Irrigação: princípios e métodos (3a ed. atual. e ampl.). Viçosa, MG: UFV.

Motta, I. S. (2008). Calda bordalesa: utilidades e preparo. Dourados, MS: Editora EMBRAPA. 
Novais, R. F., Neves, J. C. L., \& Barros, N. F. (1991). Ensaio em ambiente controlado. In A. J. Oliveira, W. E. Garrido, J. D. Araújo, \& S. Lourenço (Eds.), Métodos de pesquisa em fertilidade do solo (pp. 189-198). Brasília, DF: Editora EMBRAPA.

Pereira, P. C., Silva, T. G. F., Zolnier, S., Morais, J. E. F., \& Santos, D. C. (2015). Morfogênese da palma forrageira irrigada por gotejamento. Revista Caatinga, 28(3), 184-195. doi: 10. 1590/1983-21252015 v28n321rc

Ramos, J. P. D. F., Santos, E. M., Pinho, R. M. A., Bezerra, H. F. C., Pereira, G. A., Beltrão, G. R., \& Oliveira, J. S. (2015). Crescimento da palma forrageira em função da adubação orgânica. Revista Electrónica de Veterinária, 16(12), 1-11.

Resende, R. S., Amorim, J. R. A., Cruz, M. A. S., \& Meneses, T.N. (2014). Distribuição espacial e lixiviação natural de sais em solos do Perímetro Irrigado Califórnia, em Sergipe. Revista Brasileira de Engenharia Agrícola e Ambiental, 18, 46-52. doi: 10.1590/18071929/agriambi.v18nsupps46-s52

Richards, L. A. (1954). Diagnosis and improvement of saline and alkali soils. Washington: US Department of Agriculture.
Sales, A. T., Leite, M. L. M. V., Alves, A. Q., Ramos, J. P. F., \& Nascimento, J. P. (2013). Crescimento vegetativo de palma forrageira em diferentes densidades de plantio no Curimatú Paraibano. Tecnologia \& Ciência Agropecuária, 12(3), 37-42.

Silva, P. F., Matos, R. M., Lima, S. C., Borges, V. E., \& Dantas, J., Neto. (2015a). Produtividade de cultivares de palma forrageira em diferentes épocas de avaliação. Journal of Agronomic Sciences, 4(1), 70-81.

Silva, T. G. F., Araújo, J. T., Primo, Morais, J. E. F., Diniz, W. J. S., Souza, C. A. A., \& Silva, M. C. (2015b). Crescimento e produtividade de clones de palma no semiárido e relações com variáveis meteorológicas. Revista Caatinga, 28(2), 10-18.

Silva, R. H. D. (2018). Crescimento de palma forrageira irrigada com água salina. Tese de doutorado, Universidade Federal de Viçosa, Viçosa, MG, Brasil.

Silva, P. F., Matos, R. M., Dantas, J., Neto, Borges, V. E., Sobrinho, T. G., Bonou, S. I.,... Melo, A. P., Jr. (2020). Water and nitrogen water use efficiency in forage palm irrigated with salt water in the Neossolo. Australian Journal of Crop Science, 14(4), 683-690. doi: 10.21475/ajcs.20.14.04.p2404

Taiz, L., \& Zieger, E. (2016). Fisiologia vegetal (6a ed.). Porto Alegre: Artmed. 
